\title{
IL-18-based combinatorial adjuvants promote the NK-DC-mediated production of the CCR7 ligand CCL19 in lymph nodes from cancer patients
}

\author{
Jeffrey $L$ Wong ${ }^{1 *}$, Ravikumar Muthuswamy ${ }^{1}$, David $L$ Bartlett ${ }^{1,2}$, Pawel Kalinski ${ }^{1,2}$ \\ From Society for Immunotherapy of Cancer 28th Annual Meeting \\ National Harbor, MD, USA. 8-10 November 2013
}

Effective accumulation and interaction of mature dendritic cells (DCs) and naïve $T$ cells within lymph nodes (LNs), driven by the CCR7-CCL19/CCL21 axis, are critical for the induction of adaptive T cell immunity. Human natural killer (NK) cells activated by IL-18 exhibit unique 'helper' activity in promoting productive DC-T cell interactions, inducing dendritic cell (DC) maturation and the type-1-polarization of DC-primed T cell responses. Here we demonstrate that such IL-18-induced 'helper' NK cells uniquely induce high DC production of CCL19 in a TNF $\alpha$ and IFN $\gamma$-mediated mechanism, dependent on secondary NK cell stimulation with the additional inflammatory signals IFN $\alpha$, IL-15, IL-12, or IL-2. Helper NK cell-activated DCs promote efficient CCR7-mediated recruitment of naïve CD8+ T cells, and subsequently induce their expansion and acquisition of granzyme $\mathrm{B}$. Using an ex vivo explant culture system of LNs isolated from colorectal cancer patients, we further demonstrate enhanced expression of CCL19 in human tumor-associated lymphoid tissue induced by treatment with helper NK cell-stimulating factors. Our data indicate the ability of two-signal-activated 'helper' NK cells to promote LN production of the DC- and naive/memory T cell-attracting chemokine CCL19, and provide rationale for therapeutic application of IL-18-containing 'combinatorial adjuvants' to promote the induction of anti-tumor immunity.

\footnotetext{
Authors' details

${ }^{1}$ Department of Surgery, University of Pittsburgh School of Medicine, Pittsburgh, PA, USA. ${ }^{2}$ University of Pittsburgh Cancer Institute, Pittsburgh, PA,
} USA.

'Department of Surgery, University of Pittsburgh School of Medicine, Pittsburgh, PA, USA

Full list of author information is available at the end of the article
Published: 7 November 2013

\section{doi:10.1186/2051-1426-1-S1-O21}

Cite this article as: Wong et al:: IL-18-based combinatorial adjuvants promote the NK-DC-mediated production of the CCR7 ligand CCL19 in lymph nodes from cancer patients. Journal for ImmunoTherapy of Cancer 2013 1(Suppl 1):O21.
Submit your next manuscript to BioMed Central and take full advantage of:

- Convenient online submission

- Thorough peer review

- No space constraints or color figure charges

- Immediate publication on acceptance

- Inclusion in PubMed, CAS, Scopus and Google Scholar

- Research which is freely available for redistribution

Submit your manuscript at www.biomedcentral.com/submit 